\title{
PNSCares: The android based mobile application to manage student complaints
}

\author{
N. Illias, N. H. Abdul Hamid, Z. A. Shaffiei \\ Faculty of Computer and Mathematical Sciences, UiTM Shah Alam, Malaysia
}

\begin{tabular}{l} 
Article Info \\
\hline Article history: \\
Received Oct 17, 2019 \\
Revised Dec 28, 2019 \\
Accepted Feb 18, 2020 \\
\hline
\end{tabular}

\section{Keywords:}

Complaint

MADLC

Principle of complaint handling System usability scale

\begin{abstract}
Managing the complaint is tough to handle, efficient response to the complaints from the customer can be an indicator to measure an organization's performance. We've chosen Politeknik Nilai as one of the institutions that are facing daily complaints from the students and parents. Currently, they are using the manual form to lodge a complaint and receive the feedback via email. In this study, we developed an android based mobile application to manage the students' complaint. With mobile apps, the management can prevent the loss of complaint forms and keep track of the records. This system will send feedback and notification directly via students' mobile phone. This study referred to the ten principles for effective complaint handling by Ombudsman. We only referred to eight principles to construct the PNSCares. The methodology used to develop mobile apps is using the Mobile Application Development Life Cycle (MADLC). System Usability Scale (SUS) is used to measure the effectiveness of the mobile apps. The feedbacks from ten respondents on the PNSCares prototype are good with 72 scores in SUS for perceived usefulness and ease of use factor. Based on the result, the prototype is effective and easy to use.
\end{abstract}

This is an open access article under the CC BY-SA license.

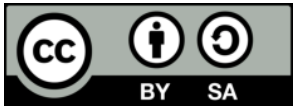

\section{Corresponding Author:}

N. H. Abdul Hamid,

Faculty of Computer and Mathematical Sciences,

UiTM Shah Alam, Selangor, Malaysia

Email: nhayati@ fskm.uitm.edu.my

\section{INTRODUCTION}

This project aims to develop an effective response to the challenges currently faced by the management in managing the complaints reported by students. The purpose of the study is to provide a smart and easy way through Android application for managing the complaint and enquiry. The current manual process will take several days, sometimes weeks to reply to each complaint and inquiries. Managing and administering using the manual method are not relevant and effective for hostels in institutions [1]. Mobile phone is one of the devices that have been carried all the time and it won't take lots of time to use the mobile application [2-4]. The main difference between both manual and automated is during the process of managing complaints. The current process is long and ineffective compared to mobile apps which is more effective that will reduce the long process and giving fast response to the students [5, 6].

Complaint definition from ISO 10002 stated that a complaint is an expression of the dissatisfaction towards an organization related to its products or the process of handling the complaints itself, where a response or resolution is explicitly or implicitly expected. It means once the complaints received, the organization should be aware and resolve each issue brought by the clients. This so-called customer centered approach was also mentioned in [7]. A complaint is an expression of dissatisfaction by a customer 
with a service offered or provided through various possible channels such as letter, email, phone call and physical claim [8]. Some of the research on handling complaints were on work-related complaints [9], hotel guests' complaints [10], using complaints to enhance quality improvement [11], and complaints handling using certain algorithms [12].

Currently, in Politeknik Nilai, through the manual practice, students get the complaint from the office and after filling in the complaints, need to submit the form to admin lobby. The management will review the forms and reply to the students via phone. Sometimes for complex cases, they need to investigate and after the discussion, the result will be sent by mail. The main objective of this study is to develop "PNSCares", an android based mobile application to improve the management of students' complaints for Politeknik Nilai. The first objective is to identify the user requirements to automate the process. The second objective is to design and develop prototype of PNSCares for Politeknik Nilai based on ten (10) Principles for Effective Complaint Handling System. The third objective is to evaluate PNSCares using Think Aloud Protocol approach for user feedback and recommendations.

This paper presents the development of PNSCares, the mobile apps to manage students' complaints. It will provide an easy platform for students to lodge complaints and for stakeholders to improve the efficiency in managing complaints [13]. In management's side, the efficiency in handling student complaints will reduce the cumbersome paperwork, manual labor as well as communication cost [14]. For students, by using the PNSCares, the current steps can be reduced, in that students will be able to receive the notification and the feedback directly to their phones.

\section{RESEARCH METHOD}

We refer to existing complaint systems to get the criteria and flow of the system to get some overview to develop the PNSCares. The three examples of existing complaint system that has been analysed is as per Table 1 below. The three examples of the e-Complaints system are Universiti Teknologi Mara (UiTM), Universiti Sains Malaysia (USM), and Universiti Malaysia Kelantan (UMK). Table 1 shows the comparison between the three existing complaint systems. This is a benchmark for us in developing the PNSCares. The features that do not exist will be enhanced in PNSCares following the requirements from the stakeholders and ten (10) principles for effective complaint handling system.

Table 1. Comparison between existing complaint system

\begin{tabular}{clccc}
\hline No. & Functions & eAduan (UiTM) & eAduan (UMK) & eAduan (USM) \\
\hline 1 & Sign Up & $\mathrm{X}$ & $\mathrm{X}$ & $\mathrm{X}$ \\
2 & Login & $\sqrt{ }$ & $\mathrm{X}$ & $\mathrm{X}$ \\
3 & Make complaint & $\sqrt{ }$ & $\sqrt{ }$ & $\sqrt{ }$ \\
4 & Choose category of complaint & $\sqrt{ }$ & $\mathrm{V}$ & $\mathrm{X}$ \\
5 & Upload picture & $\mathrm{X}$ & $\mathrm{X}$ & $\mathrm{X}$ \\
6 & Auto date/time & $\sqrt{ }$ & $\mathrm{X}$ & $\mathrm{X}$ \\
7 & List of history & $\sqrt{ }$ & $\mathrm{X}$ & $\mathrm{X}$ \\
8 & Received notification & $\mathrm{X}$ & $\sqrt{ }$ & $\sqrt{ }$ \\
9 & Check feedback & $\sqrt{ }$ & & \\
\hline
\end{tabular}

We refer to the principles of effective complaint handling by Ombudsman [15] as our guideline to develop the PNSCares though not all components of the principles were applied to PNSCares. The design of the study is like a blueprint that contains what needs to be done and how it will be accomplished [16]. Since this is a qualitative study, the data collection will be done through semi-structured interviews and usability test sessions. This concept allows for researcher's unique characteristics to have the potential to influence the data collection for the study [17]. To promote participation with collaboration in designing, developing and testing the prototype, we used a qualitative method such as narrative participatory and semi-structured interviews [18].

From the ten (10) principles of effective complaint handling, we only applied eight (8) principles which match the requirements gathered from the stakeholders. The principles are Customer Focus, Visibility, Accessibility, Responsiveness, Objective \& Fairness, Confidentiality, Accountability and Continuous Improvement. Each principle is attached in each MADLC phases. This is to ensure the effective complaint handling for Politeknik Nilai can be developed. The early stage in MADLC begins with the identification phase. During this phase, the user requirement has been identified and the related data has been gathered. All of the information has been analysed before developing the PNSCares mobile application. The principle involved is Customer Focused. Politeknik Nilai has been committed in giving feedback with appropriate 
resolution of complaints. They need a clearly communicated complaint handling process and management that values the benefits of an effective complaint handling system like PNSCares.

In the design phase, the feasibility study was conducted, and the mobile platform is determined. The idea from the first phase is developed into an initial design of the application. We used Android as a mobile platform to develop PNSCares. This is because an Android has been widely used around Politeknik Nilai based on a quick survey conducted by HEP Officer himself. Based on the interview from the previous phase, the Functional Requirements and Non-Functional Requirements are defined, and will become the guidelines in developing PNSCares.

The related diagram has been created based on the information gathered from the first phase. All the identified information has been transformed into the diagram to make it clearer. It started with the flowchart diagram of the current process and flowchart of the PNSCares. For the system functionalities of PNSCares, we created Use Case diagram to show who interact with the system and the main functions of the system. For the database design, we used a modelling technique which is ER-modelling to produce a conceptual data model. The diagrams in Figure 1 and 2 were created using entity relationship diagram (ERD) during the PNSCares development.

The design of flowchart, storyboard, interface and database is referred to the second principle which is Visibility. Visibility is to ensure that the students know how to use the PNSCares to make a complaint and the management should be aware of the complaint handling process. The flowchart design is referred to the Visibility principles on how to make and handle the complaint. The management will encourage the students to use the PNSCares by promoting the PNSCares in Politeknik area. Using the four principles at this phase which are Accessibility, Responsiveness, Objectives and Fairness and Confidentiality, we started the development of PNSCares. Accessibility is to make sure that the PNSCares is easy to access and understand by the students, HEP and Hostel Manager. The information about the complaint process are available in a variety of forms of communications. PNSCares application can accept all types of supporting documents such as an image. Figure 3 shows the storyboard for admin, while figure 4 shows the storyboard for students.

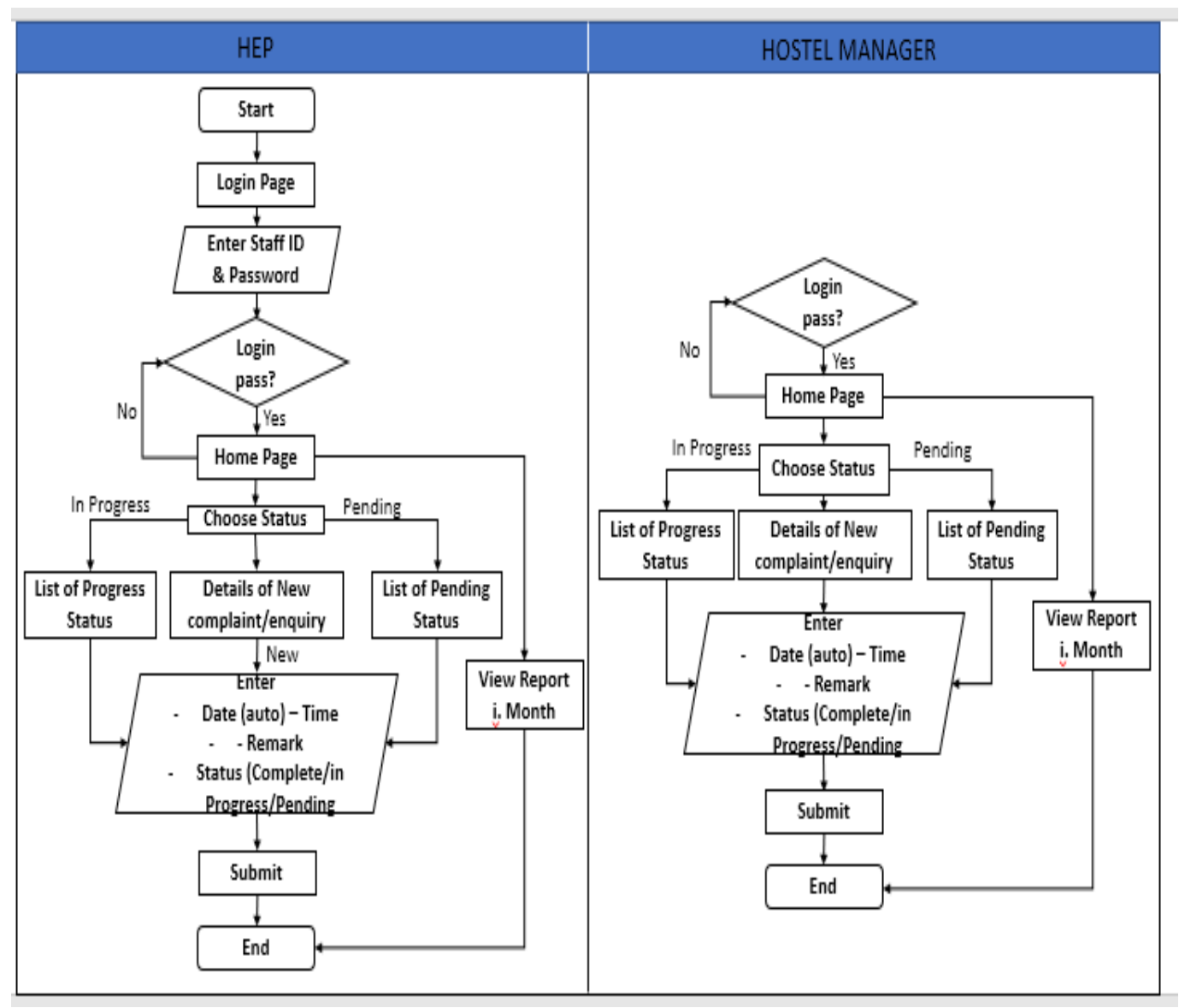

Figure 1. An overview of activity diagram for PNSCares 


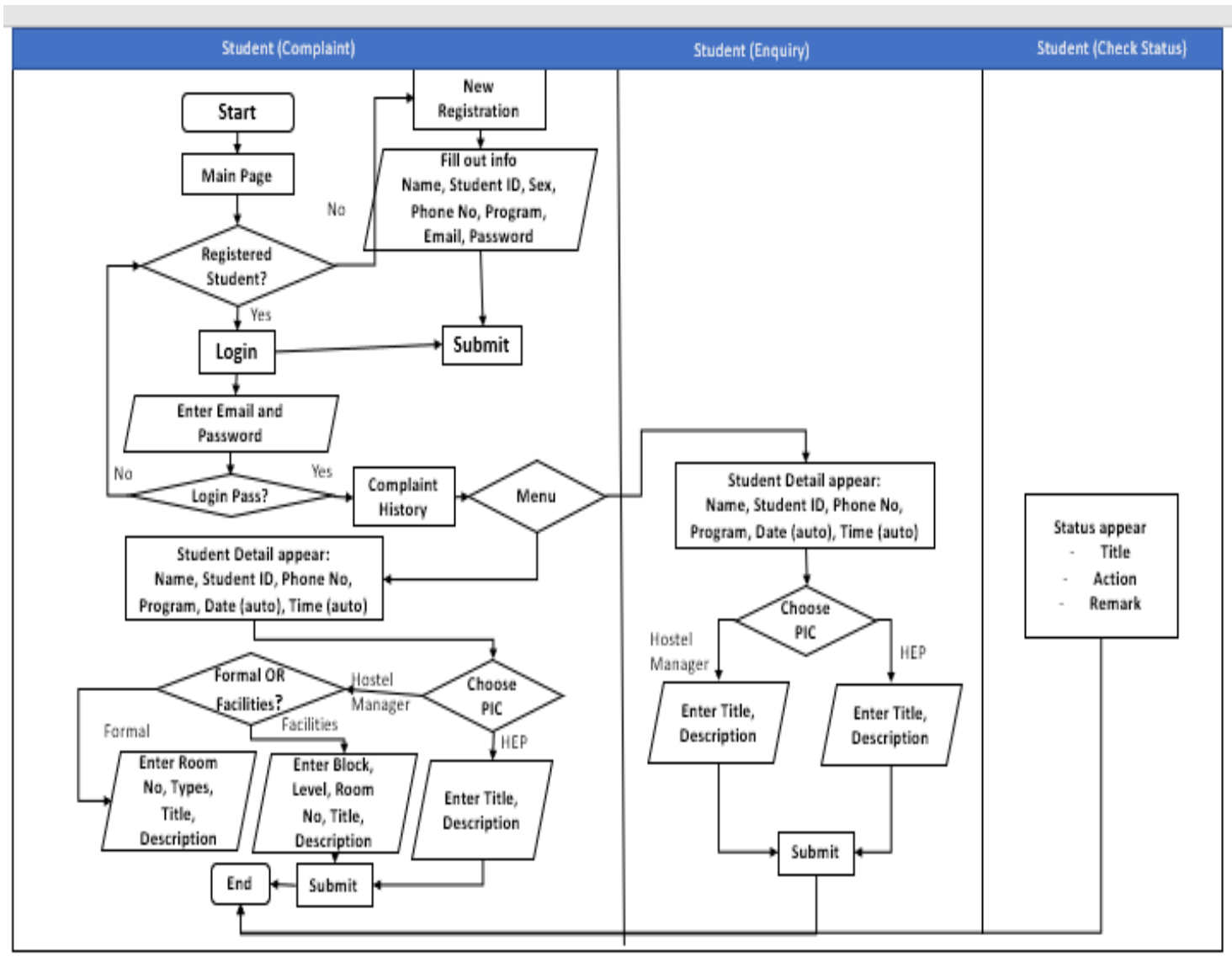

Figure 2. An overview of activity diagram for student flowchart in PNSCares

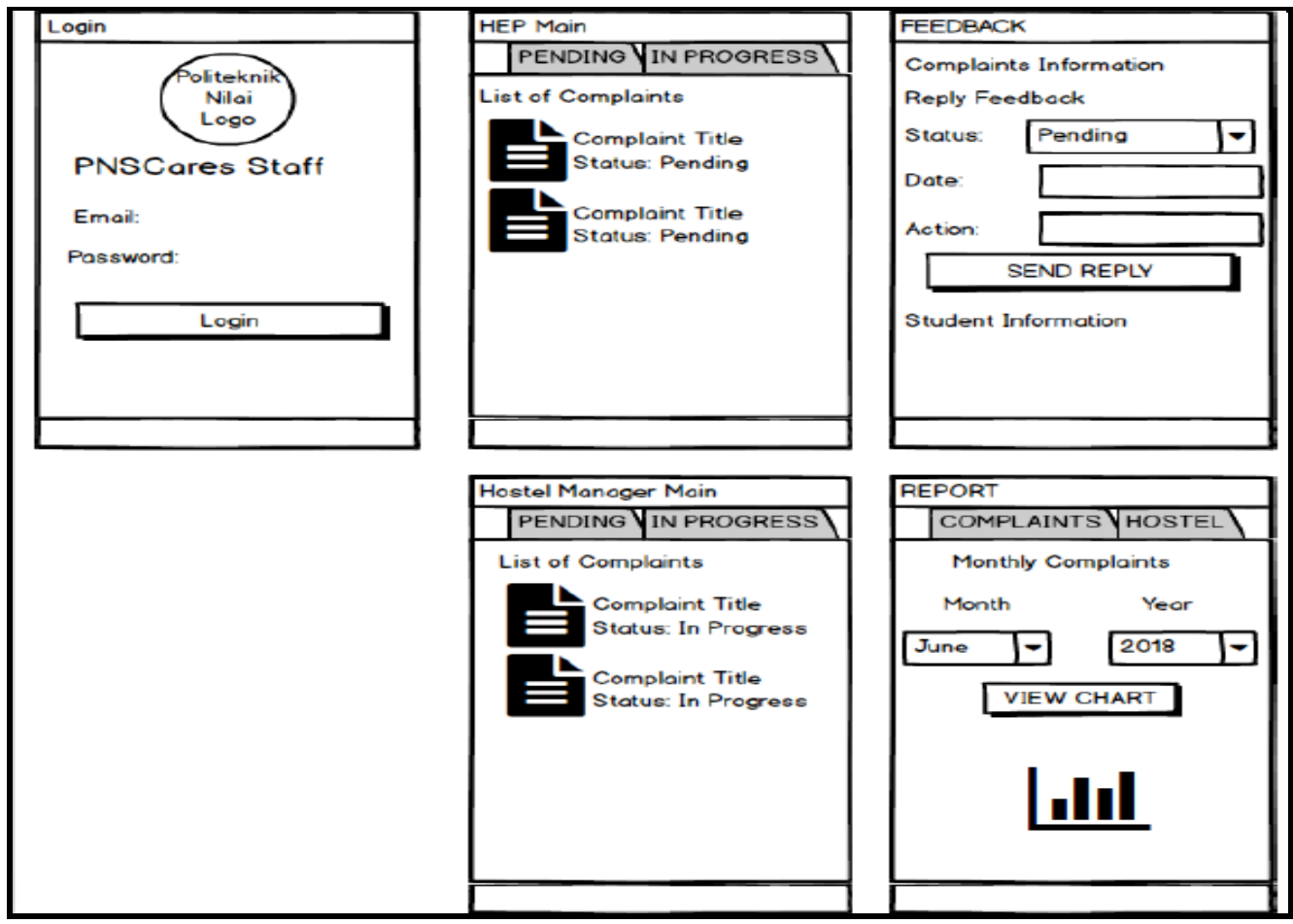

Figure 3. Storyboard of PNSCares for admin 


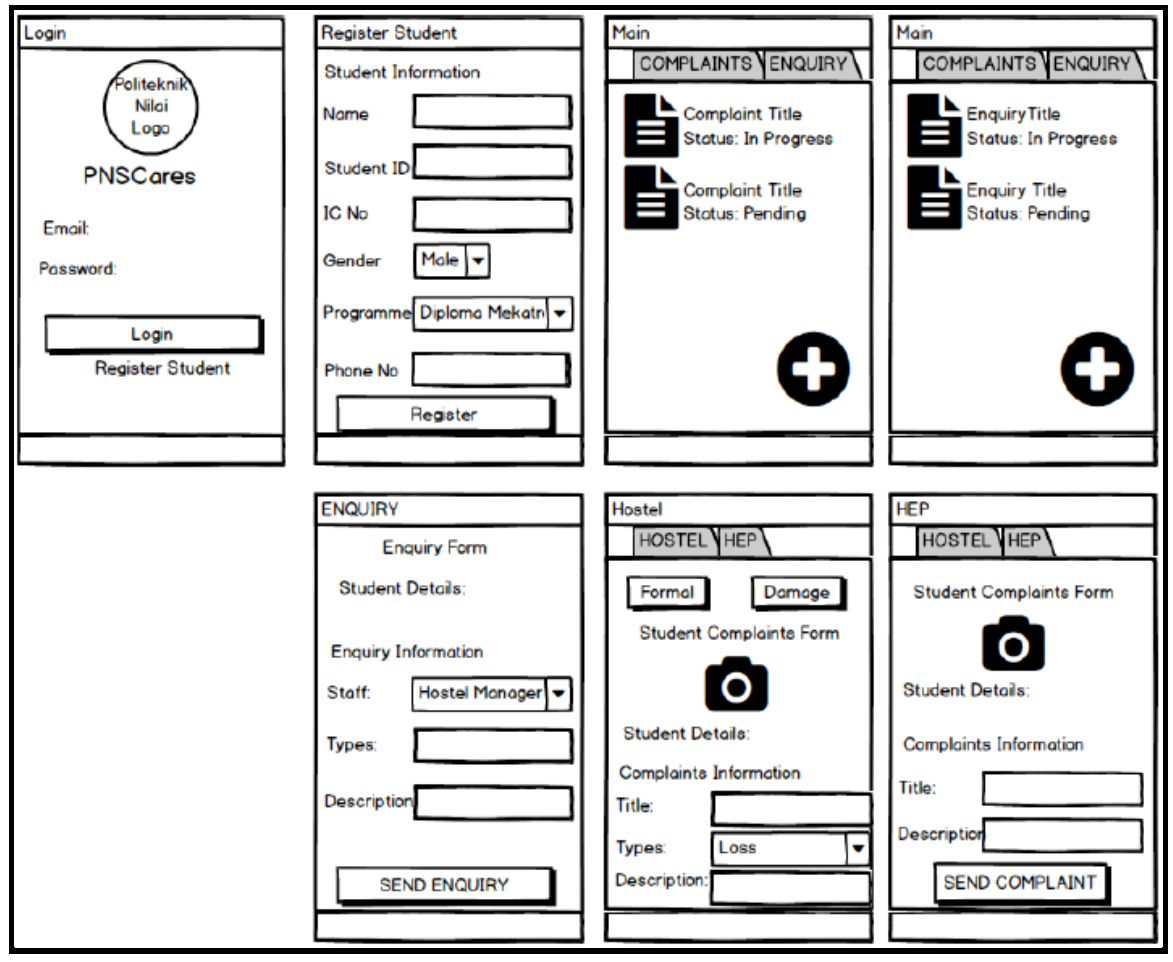

Figure 4. Storyboard of PNSCares for students

Responsiveness guides us in ensuring the complaints are acknowledge in a timely manner, addressed promptly in order of urgency. In PNSCares, the urgency is set as 'High Priority' for all types of complaints, only enquiries are set to 'Less Priority'. The student is kept informed of the progress and outcome of the complaint by the function of notification and history. HEP and Hostel Managers are the persons who will resolve complaints and empowered to handle the complaints. Any matters that are involved with authorities will not be entertained in PNSCares. The next principles, Objectives and Fairness is to ensure that the complaint handling process is fair and reasonable by response to all the complaints. With PNSCares it will not be a big problem to the management to give feedback on the spot unless there's an issue that need to be reviewed by other parties. HEP and Hostel Manager are aware of their duties in handling and making decision when dealing with the complaints. Two principals have been referred in the prototype phase, Confidentiality of each complaints and personal information of the students which is kept confidential. Only HEP and Hostel Manager has the access to PNSCares. The details are only used for the purpose of addressing the complaint and follow up actions.

As for Accountability principle, it is referred to the responsibilities while handling the complaints. HEP is responsible to respond to the complaints and enquiries for all general issues except the hostel. Meanwhile, the Hostel Manager is responsible in handling any complaints and enquiries regarding the hostel issues. The record of the complaints along with the reasons and decision has been recorded and can be tracked inside the PNSCares. There is a list of 'Pending', 'In Progress' and 'Completed' status of complaints that the management can refer. The monthly report is provided for the management to prepare the statistic of received complaints to present in the meeting. From the monthly report, the management is aware of how many unresolved complaints need to be handled. The last principle that we refer to is Continuous Improvement. With PNSCares, the management can identify which types of complaints with the highest report by tracking the record from the PNSCares. With the complaints, the management can improve the services and implement improved practices to be a better institution.

\section{RESULTS AND DISCUSSION}

We tested the user experience on the system by using the System Usability Scale (SUS) [19-21]. The System Usability Scale (SUS) is a ten (10) question Likert Scale where each question rated from 1 to 5 [22]. Other method includes Technology Acceptance Model (TAM) [23] [24]. We did a comparative study of the identified three (3) mobile apps for Complaints management-iKepoh, Aduan MSNS 
and KLCares. The comparative study of the three apps is depicted in Table 2. The comparative study of the applications is reviewed based on apps functionality.

Table 2. Comparison between mobile apps

\begin{tabular}{rlcccccc}
\hline \multicolumn{7}{c}{ Categories } \\
No. & & App name & $\begin{array}{c}\text { Login \& } \\
\text { profile }\end{array}$ & $\begin{array}{c}\text { Submit } \\
\text { complaints }\end{array}$ & $\begin{array}{c}\text { Complaints } \\
\text { history }\end{array}$ & $\begin{array}{c}\text { Status } \\
\text { notification }\end{array}$ & $\begin{array}{c}\text { Feedback } \\
\text { response }\end{array}$ \\
\hline 1 & iKepoh & $\sqrt{ }$ & $\sqrt{ }$ & $\sqrt{ }$ & $\sqrt{ }$ & $\sqrt{ }$ \\
2 & Aduan & $\sqrt{ }$ & $\sqrt{ }$ & $\sqrt{ }$ & $\sqrt{ }$ & $\sqrt{ }$ \\
3 & MPSNS & KLCares & $\sqrt{ }$ & $\sqrt{ }$ & $\mathrm{X}$ & $\mathrm{X}$ & $\sqrt{ }$ \\
\hline
\end{tabular}

Stakeholders interviews were conducted with the aim of obtaining specific information on process flow and requirements of the system. The focus during the interview is to get the flow of the current process of managing the student complaints and to get the overview of the overall structure in HEP department and hostel unit. This is important because in the initial phase we have to understand the flow and to identify user requirements from the stakeholder [25]. We have evaluated the scores from ten (10) participants and the result is tabulated in Figure 5. In order to use the SUS, each question is rated on a five-point scale of "Strongly Disagree" to "Strongly Agree". From the result shown in Figure 2 below, the average score is seventy-two (72) which means the prototype of PNSCares is "Good" and ready to be implemented at Politeknik Nilai.

\begin{tabular}{|c|c|c|c|c|c|c|c|c|c|c|}
\hline \multicolumn{11}{|c|}{ 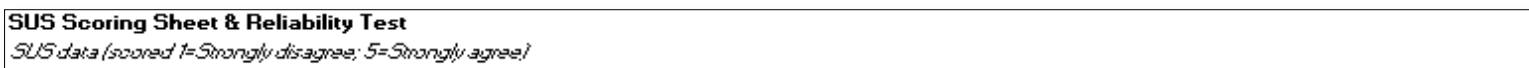 } \\
\hline & Q1 & $\mathrm{Q} 2$ & $\mathrm{Q3}$ & $\mathrm{Q} 4$ & Q5 & Q6 & Q7 & $\mathrm{Q8}$ & Q9 & Q10 \\
\hline Participants & $\begin{array}{l}\text { I think that I } \\
\text { would like to } \\
\text { use this } \\
\text { system } \\
\text { frequently }\end{array}$ & $\begin{array}{l}\text { I found the } \\
\text { system } \\
\text { unneccessarily } \\
\text { complex }\end{array}$ & $\begin{array}{l}\text { It thought the } \\
\text { system was } \\
\text { easy to use }\end{array}$ & $\begin{array}{l}\text { Ithink that I } \\
\text { would need the } \\
\text { support of a } \\
\text { technical } \\
\text { person to be } \\
\text { able to use this }\end{array}$ & $\begin{array}{l}\text { I found the } \\
\text { various } \\
\text { functions in } \\
\text { this system } \\
\text { were well } \\
\text { integrated }\end{array}$ & $\begin{array}{l}\text { It thought there } \\
\text { was too much } \\
\text { inconsistency } \\
\text { in this system }\end{array}$ & $\begin{array}{l}\text { I would imagine } \\
\text { that most } \\
\text { people would } \\
\text { learn this } \\
\text { system very } \\
\text { quickly }\end{array}$ & $\begin{array}{l}\text { I found this } \\
\text { system very } \\
\text { cumbersome } \\
\text { to use }\end{array}$ & $\begin{array}{l}\text { I felt very } \\
\text { confident } \\
\text { using the } \\
\text { system }\end{array}$ & $\begin{array}{l}\text { I needed to } \\
\text { learn a lot of } \\
\text { things before I } \\
\text { could get } \\
\text { going with this } \\
\text { system }\end{array}$ \\
\hline P1 & 5 & 4 & 4 & 1 & 4 & 2 & 5 & 1 & 5 & 2 \\
\hline P2 & 5 & 4 & 4 & 2 & 4 & 2 & 4 & 2 & 5 & 2 \\
\hline P3 & 4 & 4 & 3 & 2 & 4 & 3 & 4 & 2 & 4 & 2 \\
\hline P4 & 4 & 4 & 4 & 2 & 4 & 2 & 3 & 2 & 4 & 2 \\
\hline P5 & 4 & 3 & 4 & 2 & 3 & 3 & 4 & 2 & 4 & 2 \\
\hline P6 & 5 & 4 & 3 & 1 & 4 & 2 & 5 & 1 & 5 & 2 \\
\hline P7 & 4 & 3 & 3 & 2 & 3 & 2 & 4 & 2 & 4 & 2 \\
\hline P8 & 4 & 3 & 4 & 2 & 4 & 2 & 4 & 2 & 4 & 2 \\
\hline P9 & 5 & 4 & 3 & 1 & 4 & 2 & 5 & 1 & 5 & 2 \\
\hline P10 & 4 & 3 & 3 & 2 & 3 & 2 & 3 & 2 & 3 & 2 \\
\hline & & & & & & & & & & \\
\hline & & & & \multicolumn{2}{|c|}{ Grading SUS Key } & & & & & \\
\hline & & & & $92=$ & Best imaginab & & & & & \\
\hline & & & & 85 & Excellent & & & & & \\
\hline & & & & 72 & Good & & & & & \\
\hline & & & & 52 & DKIF air & & & & & \\
\hline & & & & 38 & Poor & & & & & \\
\hline
\end{tabular}

Figure 5. SUS scoring sheet test

\begin{tabular}{|c|c|c|c|}
\hline \multicolumn{4}{|c|}{ Scales } \\
\hline Odd items & Even items & SUS score (1100) & Grades \\
\hline 18 & 15 & 82.5 & $\mathrm{~B}$ \\
\hline 17 & 13 & 75 & C \\
\hline 14 & 12 & 65 & D \\
\hline 14 & 13 & 67.5 & D \\
\hline 14 & 13 & 67.5 & D \\
\hline 17 & 15 & 80 & $\mathrm{~B}$ \\
\hline 13 & 14 & 67.5 & D \\
\hline 15 & 14 & 72.5 & C \\
\hline 17 & 15 & 80 & B \\
\hline 11 & 14 & 62.5 & D \\
\hline & Average scc & 72 & C \\
\hline
\end{tabular}

Figure 5. SUS scoring sheet test (continue) 
Based on the SUS result and testing session with the user, they found that PNSCares is the must have mobile apps in institution. The apps is easy to use, friendly and well function. The ineffective process in current complaints handling has been improved with the development of PNSCares by referring to the eight (8) principles for effective handling complaint. Figure 6 shows the improvement after PNSCares implementation. The long process shown in the red line, has been removed and the students will get a quick feedback from the management. The two way communications between the students and management would help improve the complaints management in Politeknik Nilai.

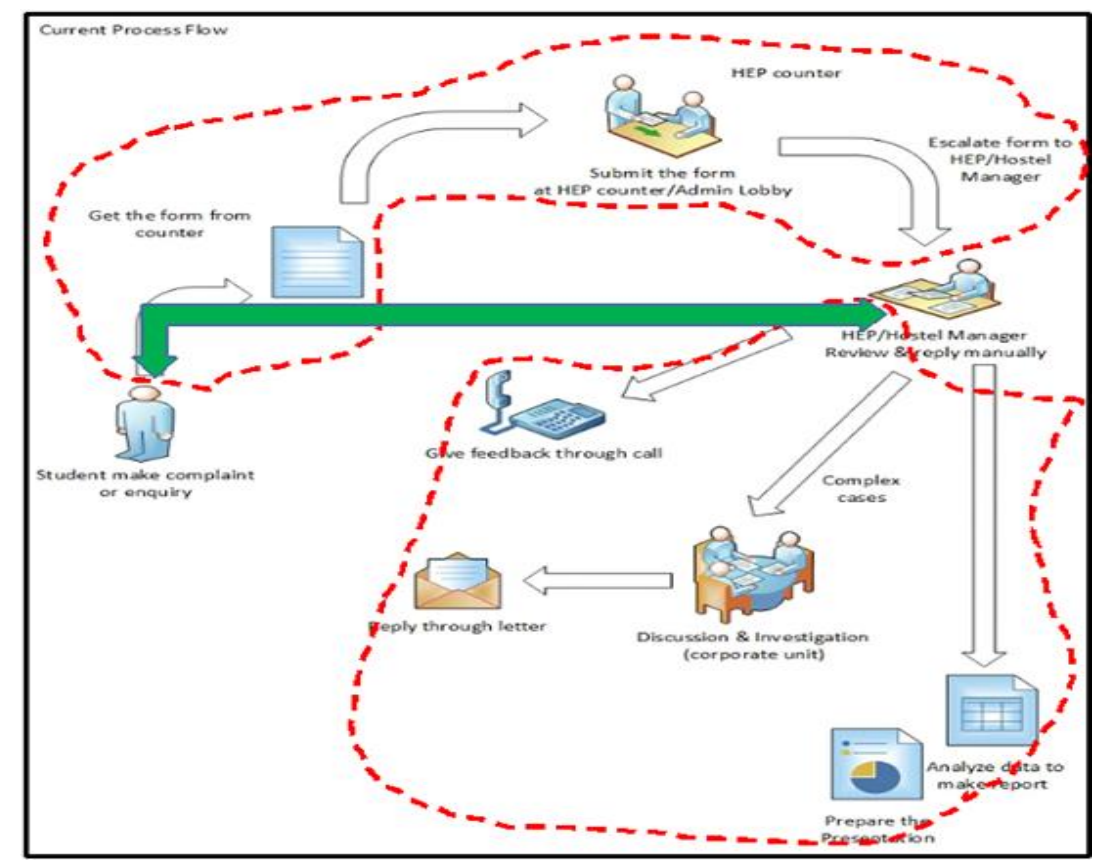

Figure 6. Overview of the improvement after PNSCares implementation

\section{CONCLUSION}

This paper presents the android based mobile application to manage student complaints. The current complaint handling process in Politeknik Nilai is ineffective because it didn't follow any guideline or principles for an effective handling complaint system in the future. The purpose of the study is to automate the current manual process to help the management in handling the complaint issues.

By referring to the ten (10) principles for effective complaint handling, we managed to develop a prototype of PNSCares. The principles are User Focused, Visibility, Accessibility, Responsiveness, Objectivity and fairness, Confidentiality, Remedy, Review, Accountability and Continuous Improvement. The eight (8) principles previously mentioned is excluding the Remedy and Review. Following this eight (8) principles, the process of effective complaint handling was achieved.

We also found that the PNSCares is ready to be implemented because of the "Good" result in SUS scores. PNSCares has been proven as an effective mobile Apps in managing complaints. The PNSCares is supposed to be used by the staff and public but in the meantime, it is only available for students. Additional research needs to be conducted to determine how effective the complaint handling is practiced in Malaysian institution. In future, PNSCares may be proposed to all Politeknik in Malaysia aimed at managing complaints and enquiries.

\section{ACKNOWLEDGEMENTS}

We would like to thank the Faculty of Computer and Mathematical Sciences, Universiti Teknologi MARA, Malaysia for the support throughout this research. We would also like to express our high gratitude to Ministry of Education (MOE) for funding this paper submission via FRGS grant (FRGS/1/2108/ICT 01/UITM/02/2). We would also like to thank the Institute of Quality and Knowledge Advancement (InQKA), Universiti Teknologi MARA, Malaysia for funding the publication of this research. We would also like to thank Politeknik Nilai, Malaysia for their support in this research. 


\section{REFERENCES}

[1] K Ayanlowo et al., "Development of an automated hostel facility management system," Journal of Science and Engineering, vol. 5, no. 1, pp. 1-10, 2014.

[2] C. Leung et al., "Should you use the app for that?," Proceedings of the ACM on Internet Measurement Conference, pp. 365-372, 2016.

[3] A. Abadi et al, "Mobile computing to support sustainability," Proceedings of the 3rd International Workshop on Mobile Development Lifecycle, pp. 54-57, 2015.

[4] Z. A. Nasruddin et al., "Evaluating construction defect mobile application using think aloud," Malaysian Journal of Computing, vol. 2, no. 2, pp. 162-171, 2018.

[5] G. V. Bharambe, "Analytical study for the development of smart campus in college," Imperial Journal of Interdisciplinary Research, vol. 3, no. 1, pp. 1687-1693, 2017.

[6] T Bomble and R. Raut, "Android based complaint management system for municipal corporation," International Journal of Engineering Research and Applications, vol. 5, no. 4 part 3,, pp. 64-66, 2015.

[7] N. H. Ariffin and N. Daud, "Customer centered service in Malaysia: A case study in Malaysian Public Universities," Malaysian Journal of Computing, vol. 4, no. 1, pp. 214-224, 2019.

[8] B. Stauss and A. Schoeler, "Complaint management profitability: What do complaint managers know?," Managing Service Quality: An International Journal, vol. 14, no. 2/3, pp. 147-156, 2004.

[9] Q. M. Sagita, Y. Setyaningsih and S. Sulistiyani "Determinant factors of work-related complaints," International Journal of Public Health Science, vol. 7, no. 1, pp. 46-50, 2018.

[10] B. A. Sparks, and V. Browning, "Complaining in cyberspace: The motives and forms of hotel guests' complaints online," Journal of Hospitality Marketing \& Management, vol. 19, no. 7, pp. 797-818, 2010.

[11] S. Y. Hsieh, "Using complaints to enhance quality improvement: Developing an analytical tool," International Journal of Health Care Quality Assurance, vol. 25, no. 5, pp. 453-461, 2012.

[12] R. Wongso et al., "Complaint analysis in indonesian language using WPKE and RAKE algorithm," International Journal of Electrical and Computer Engineering, vol. 8, no. 6, pp. 5311-5317, 2018.

[13] S. Lewis, "Qualitative inquiry and research design: Choosing among five approaches," Health Promotion Practice, vol. 16, no. 4, pp. 473-475, 2015.

[14] J. H. Walker, "E-complaining: A content analysis of an Internet complaint forum," Journal of Services marketing, vol. 15, no. 5, pp. 397-412, 2001.

[15] P. Srikant, et al., "College management system," International Journal of Engineering and Technology, vol. 3, no. 5, pp. 1-3, 2016.

[16] Ombudsman Western Australia. 2017, “Guideline on complaint handling," Retrieved from http://www.ombudsman.wa.gov.au/Agencies/Complaints_pro cesses.htm.

[17] T. Vithani, and A. Kumar, "Modeling the mobile application development lifecycle," Proceedings of the International MultiConference of Engineers and Computer Scientists, vol. 1, pp. 596-600, 2014.

[18] A.E. Pezalla, et al., "Researching the researcher-as-instrument: an exercise in interviewer self-reflexivity," Qual Res, vol. 12, no. 2, pp. 165-185, 2012.

[19] J. R. Lewis, and J. Sauro, "The factor structure of the system usability scale," Proceedings of the $1^{\text {st }}$ International Conferences on Human Centered Design, pp. 94-95, 2009.

[20] J. Sauro, "SUPR-Q: A comprehensive measure of the quality of the website user experience," Journal of Usability Studies, vol. 10, no. 2, pp. 68-86, 2015.

[21] J. Sauro, and J. R. Lewis, "When designing usability questionnaires, does it hurt to be positive?," Proceedings of the 2011 Annual Conference on Human Factors in Computing Systems. CHI '11, 2215.

[22] A. Deraman, and S. Fouad, "Managing usability evaluation practices in agile development environments," International Journal of Electrical and Computer Engineering, vol. 9, no. 2, pp. 1288-1297, 2019.

[23] Z. A. Shaffiei, et. al., "A study of user's acceptance and perception towards Campus Management System (CMS) using Technology Acceptance Model (TAM)," 2011 3rd International Congress on Engineering Education, pp. 128-131, 2011.

[24] M. Mokhsin et. al., "Measurement of user's acceptance and perceptions towards Campus Management System (CMS) Using Technology Acceptance Model (TAM)," International Journal of Information Processing and Management, vol. 2, no. 4, pp. 34-46, 2011.

[25] N.A. Ahmad, et al., "An analysis of user requirement for Halal Compliant Mobile Application (HCMA)," Contemporary Management and Science Issues in the Halal Industry, pp 332-334, 2019. 